\title{
Athletic Field Use Capacity 1
}

Grady L. Miller²

A common question is how much play can a field withstand? There is no definitive answer to that question because field wear is influenced by so many variables. Schools and municipalities are facing increasing legal questions and liability regarding injuries associated with poorly designed, constructed, or maintained facilities. There is a struggle to accommodate all participating groups without damaging the fields. If fields are overused, then the likelihood of a player becoming injured due to poor field conditions increases.

\section{Planning}

An ideal situation is to have adequate numbers of fields so that use can be limited. It is best to have game and practice fields dedicated to only one sport to eliminate compound wear of two or more sports. Additionally, there should be a sound turf maintenance program that promotes turf growth and recovery. Unfortunately, budgets for field management are often the most limiting factor.

Good fields begin with a sound construction strategy, and careful planning is imperative for long-term success. This publication is not intended to address construction, but it is helpful to consider some basic concepts when planning for a new field.
Questions to ask in the planning phase include:

1. What are the expectation levels for use and performance?

2. Are these expectations realistic considering the proposed construction and maintenance budgets?

3. Is the field manager qualified for the proposed facility?

4. Are sufficient machinery and labor available for necessary maintenance in a timely manner?

5. Will the use of the field increase over time, and if so, will the maintenance budget be increased?

\section{Construction}

There are several construction tips that can be used to maximize field durability. It is important that a field have adequate drainage. Since wet fields are more prone to damage than dry fields, adequate drainage not only prevents rainouts, but can also prolong the use of a field. Drainage can be achieved through the use of surface flow off crowns or via subsurface drainage lines. Subsurface drainage depends on good infiltration of the field. For this

1. This document is ENH 991, one of a series of the Environmental Horticulture Department, Florida Cooperative Extension Service, Institute of Food and Agricultural Sciences, University of Florida. Original publication date October 21, 2004. Visit the EDIS Web Site at http://edis.ifas.ufl.edu.

2. Grady L. Miller, Associate Professor, Environmental Horticulture Department, Institute of Food and Agricultural Sciences, University of Florida, Gainesville, FL 32611.

The Institute of Food and Agricultural Sciences (IFAS) is an Equal Employment Opportunity - Affirmative Action Employer authorized to provide research, educational information and other services only to individuals and institutions that function without regard to race, creed, color, religion, age, disability, sex, sexual orientation, marital status, national origin, political opinions or affiliations. For information on obtaining other extension publications, contact your county Cooperative Extension Service office. Florida Cooperative Extension Service / Institute of Food and Agricultural Sciences / University of Florida / Larry R. Arrington, Interim Dean 
reason, the surface of a sand-based field will drain much more effectively than the surface of a field that relies on surface flow alone. In addition, sand-based fields are not as likely to compact. A compacted field generally has lower water infiltration, so the surface may remain wet for longer periods of time following a moderate rain.

In terms of turfgrasses, bermudagrass is the ideal turfgrass surface for Florida's athletic fields. It forms a tight, resilient playing surface with high wear tolerance and fast recuperative potential. These traits are best in the summer and early fall when it is actively growing. If the turf goes dormant in late fall or winter, the above-ground tissue can be easily worn off during heavy play. Maintaining reasonable fertility practices during the fall can help the turf recover through the winter and spring months. Bahiagrass is an alternative that should only be used on low-maintenance recreation fields, not fields designed for competitive play.

\section{Use}

The question still has not been answered regarding how much use a field can handle. This question is best answered using actual data on field use from previous years. This requires some careful documentation of games, practices, and other events. As the demand for fields increases, it seems that more entities are starting to track field use. Probably the easiest data to track is the number of hours the fields are used during the year.

Using data from a number of fields located around the state of Florida, and talking with turf managers and municipality supervisors, I have made a few general estimates related to field use (Table 1). These educated predictions are for football and soccer fields that are used nearly year round. Baseball and softball should be evaluated differently since so much of the game is played on a clay infield. The estimates assume the field is surfaced with a quality bermudagrass and begins the year with good coverage. The values relate to well-constructed fields that receive at least moderate maintenance and are used under reasonable conditions. The reality is that it only takes one extremely wet game to destroy a field. The values are based on all the events that occur on the field, including practices. Practices can also cause appreciable damage due to their repetitive nature in particular areas of a field, so they must also be put into the equation.

The number of events a field can handle will ultimately depend upon field construction, weather conditions during the season (especially just before and during games), maintenance practices, recuperative periods, and the time of the year.

To maximize field conditions,

1. Make every effort to begin the sporting season with 100 percent turf coverage.

2. Adjust maintenance practices to address the condition of the fields.

3. Schedule recuperative times during the season, realizing that non-overseeded bermudagrass fields will not recuperate very quickly in the late fall or winter months.

4. Overseed if you expect excessive wear during cooler months that are not conducive for bermudagrass growth. The need and timing for overseeding also depends on your location. Below Orlando, overseeding is typically not necessary.

Obviously, the more traffic you put on the field, the faster the turf declines. Also, particular sports cause more severe damage in localized areas on the field. Football tends to cause extreme wear between the hash marks. Soccer wears the quickest in the middle of the field, in front of the goal mouths, along the sidelines (due to linesmen) and the corner kick areas. Any repetitive action on the same area of the field accelerates wear. That is why practices and warm-up drills are often more damaging than games. But it is not just the athletes on the field that can cause wear problems. A marching band is extremely hard on a field because they tend to march along the same lines all the time, both during a game and in practice. Cheerleaders and pep squads during games may also result in turf damage due to heavy use in a confined area.

You can get some reduction in traffic damage by doing the following: 
1. Restrict use when soil is very wet

2. Restrict use when soil is very dry and turf is wilted

3. Always have coaches rotate heavy play areas during practices

4. If possible move soccer field sidelines of field during the year

5. On game fields, restrict all practices to a minimum

6. Restrict field use when grass is dormant

7. Do not allow unofficial play

8. Use tarps (covers) on bench areas to reduce severe wear by coaches and team members, and on sideline areas used by the cheerleaders

Table 1. Expected field condition based on hours of field use per year.

\begin{tabular}{||l|c||}
\hline \multicolumn{1}{|c|}{ Field Condition } & Hours per Year \\
\hline Sustain good field conditions & 200 hours or less \\
\hline $\begin{array}{l}\text { Fair to good field conditions, some thinning } \\
\text { turf and localized wear areas }\end{array}$ & 400 to 600 hours \\
\hline $\begin{array}{l}\text { Significant turf loss, field surface damage, } \\
\text { increased potential for athlete injury }\end{array}$ & Over 800 hours \\
\hline \hline
\end{tabular}

\section{Conclusion}

In most cases you will need to educate field users. Most do not understand the damage that they can cause. While it may be obvious to you that the field is too wet for play, it is not obvious to most field users. Close fields when it is necessary. If you are not allowed to close the fields, at least make the decision makers aware of the potential short- and long-term damage that may result from field use given the situation. Unfortunately, some fields are scheduled the same as basketball courts or hard-surface tennis courts, without consideration of wearability of the turf surface. The field manager is in the best position to decide how much is too much. 